\title{
ANALYSIS OF RESULTS OF MEASURES PERFORMED TO INCREASE ENERGY EFFICIENCY IN VASIL KARAGIOZOV HIGH SCHOOL OF YAMBOL, BULGARIA
}

\author{
Ivan Binev \\ Trakia University, Faculty of Technics and Technology \\ Graf Ignatiev 38, 8600, Yambol, Bulgaria, \\ e-mail: ivan.binev@trakia-uni.bg
}

\begin{abstract}
The report analyzes the results of the implemented measures to improve energy efficiency in Vasil Karagiozov High school of Yambol, Bulgaria. Energy savings are determined by measuring and/or calculating energy consumption with previously adopted baseline levels, implementing a measure or program to improve energy efficiency by providing normalized corrections corresponding to the impact of specific climatic conditions on energy use. A reference heating energy consumption of $38.62 \mathrm{kWh} / \mathrm{m} 2$ was determined after the renovation of the building. Comparing the reference energy costs for heating before and after the implementation of the energy saving measures show a real decrease of the energy consumption for heating by $53.44 \%$. Compared to the reference energy consumption for heating before and after the energy saving measures show an actual reduction of energy consumption for heating by $47.86 \%$.
\end{abstract}

Keywords: heat transfer coefficient, energy conservation measures, energy consumption, heated area, heated space.

\section{INTRODUCTION}

In June 2008, in order to comply with the requirement of Article 19, Paragraph 2, of the Energy Efficiency Act [1] and in connection with the application for external financing of energy efficient reconstruction of the building of Vocil Karagyozov High school of Yambol, for energy efficiency by "Max Max Effect" ELTD, Sliven [2].

Energy calibration modeling has been done to calibrate and normalize the model. The annual reference energy consumption for heating is calculated during the calibration of the model $82,95 \mathrm{kWh} / \mathrm{m}^{2}$.

Normalization of the model sets an annual baseline energy consumption for heating of 159.5 $\mathrm{kWh} / \mathrm{m}^{2}$ to maintain the normative temperature required for the existing building condition.

The reference annual energy consumption for heating $-34.5 \mathrm{kWh} / \mathrm{m}^{2}$ is calculated for the specific building, the values of the reference characteristics of the building envelope structures being adopted according to the technical requirements of the norms in force at the time of the energy efficiency audit.

The comparison shows that the normalized heating energy consumption is 4.6 times higher than the building reference [2].

As a result of the survey, the following ESMs (Energy saving measures) were implemented:

- Thermal insulation of external walls;

- Thermal insulation of the roof;

- Replacement of wooden and steel windows with PVC with double glazing;

- Thermal insulation of a floor bordering an unheated basement and a floor bordering on outside air;

- ESM for heating and heating;

- Introduction of a combined DHW (domestic hot water) system.

IRTIIE Vol. 6, No. 4, 2018 ISSN 1314-8788 (print), ISSN 1314-8796 (online), doi: 10.15547/artte.2018.04.004 


\section{IRTITE}

Ipplied Resererthes in Technics, Technologies and Bduration Journal of the Faculty of Technics and Technologies, Trakia University https://sites.google.com/a/trakia-uni.bg/artte/

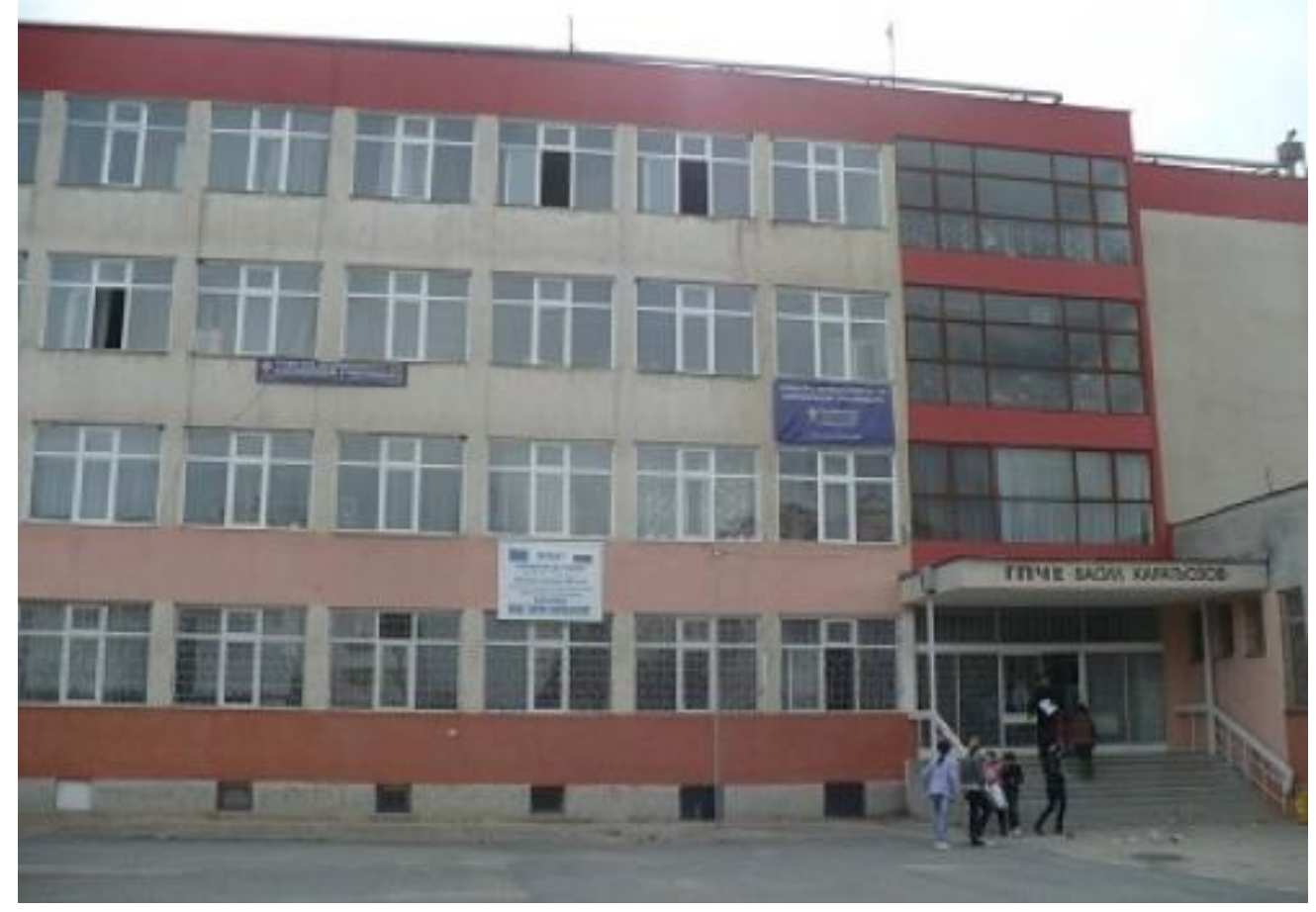

Figure 1. Facade of Vassil Karagyozov High school

The purpose of the publication is to analyze the results of the implemented energy saving measures prescribed in the Energy Efficiency Survey of the building of Vasil Karagiozov High school building in Yambol, Bulgaria.

\section{MATERIAL AND METHODS}

The methods for assessing energy savings have been developed on the basis of Art. 22, para. 3, item 4 of the Ordinance under Art. 9, para. 2 of the Energy Efficiency Act [1]. Energy savings are determined by measuring and/or calculating energy consumption with previously adopted baseline levels, implementing a measure or program to improve energy efficiency by providing normalized corrections corresponding to the impact of specific climatic conditions on energy use.

The amount of energy saved is equal to the difference between the energy used before the implementation of the measure or program to improve energy efficiency and energy use measured after this introduction [3].

The model study on energy consumption of buildings aims at:

- Determination of the energy consumption and energy performance indicators of the building;

- Getting the energy needed to maintain the microclimate in the building;

- Comparison with the reference energy consumption of the building;

- Where necessary, specify energy saving measures to obtain an energy efficiency certificate.

General input data to create a building model:

- geographic area - Yambol, climatic zone 6. Climate database parameters are in accordance with the calculation method for determining the annual reference energy consumption;

IRITIE Vol. 6, No. 4, 2018 ISSN 1314-8788 (print), ISSN 1314-8796 (online), doi: 10.15547/artte.2018.04.004 


\section{ARTITI

- type of building - school;

- operating norms for building envelope structures and elements at the time of construction of the building - 1989;

- mode of use - number of students and staff, schedule occupants, schedule heating;

- the characteristics of the enclosing elements.

Model calibration. Calibration of the model aims to determine the reference energy consumption for the year with the highest specific cost. In determining it, the total annual energy consumption, the annual heating cost, the days of the respective climate zone and the days for the year for which the reference energy consumption is determined.

\section{RESULTS AND DISCUSSION}

Data collected from the energy invoices for heating before the renovation of the building for three consecutive years - 2005, 2006, 2007, 2015 and 2016 after the prescribed energy saving measures have been collected and processed. They are presented in Table 1.

The consumption of heat during the implementation of the project is not the subject of the study.

Table 1. Annual heat consumption by years, reported by invoice data

\begin{tabular}{|c|c|c|c|c|c|c|c|}
\hline \multirow{2}{*}{ Object studied } & \multicolumn{7}{|c|}{ Heat energy, MWh } \\
\cline { 2 - 8 } & 2005 & 2006 & 2007 & $\begin{array}{c}\text { Average } \\
\text { annual cost } \\
\text { before ESM } \\
\text { (2005-2007) }\end{array}$ & 2015 & 2016 & $\begin{array}{c}\text { Average } \\
\text { annual cost } \\
\text { before ESM } \\
(2015-2016)\end{array}$ \\
\hline Vasil Karagiozov High school & 637,49 & 825,46 & 669,37 & 710,77 & 303,32 & 320 & 311,66 \\
\hline
\end{tabular}

In Figure 2 is the average annual energy consumption for heating before and after the implementation of the energy saving measures. After renovating the building, this cost has decreased 2.3 times.

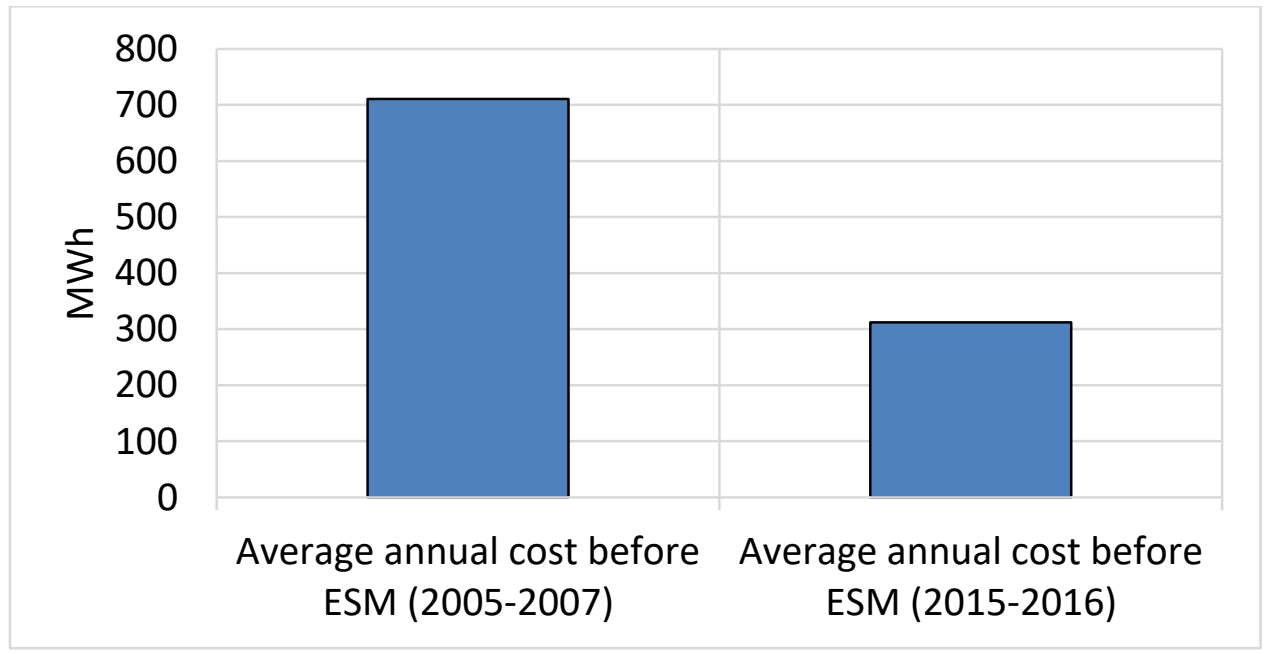

Figure 2. Average annual energy consumption for heating before and after the implementation of energy saving measures

In order to avoid inaccurate interpretation of the invoice data, Table 2 shows the energy consumption data related to the heating days (DD) for the same heating periods [5].

IRTIIE Vol. 6, No. 4, 2018 ISSN 1314-8788 (print), ISSN 1314-8796 (online), doi: 10.15547/artte.2018.04.004 


\section{IRTITE}

Ipplied Researleches in Technics, Technologies and Bductition Journal of the Faculty of Technics and Technologies, Trakia University https://sites.google.com/a/trakia-uni.bg/artte/

Table 2. Specific energy consumption [MWh/ DD]

\begin{tabular}{|l|c|c|c|c|c|}
\hline \multirow{2}{*}{ Vasil Karagiozov High school } & \multicolumn{5}{|c|}{ Year } \\
\cline { 2 - 6 } & $\mathbf{2 0 0 5}$ & $\mathbf{2 0 0 6}$ & $\mathbf{2 0 0 7}$ & $\mathbf{2 0 1 5}$ & $\mathbf{2 0 1 6}$ \\
\hline Power consumption, MWh & 637,49 & 825,46 & 669,37 & 303,32 & 311,66 \\
\hline Day degrees, DD & 2501 & 2584 & 2317 & 2294,50 & 2105,7 \\
\hline Specific power consumption, MWh/DD & 0,255 & 0,319 & 0,289 & 0,132 & 0,148 \\
\hline
\end{tabular}

At 2501 day degrees (DD) for 2005, the energy consumption is $637.49 \mathrm{MWh}$ and the specific energy consumption is $0.255 \mathrm{MWh} / \mathrm{DD}$. Similarly, at 2584 days in 2006, the energy consumption was 825.46 MWh and the specific energy consumption was $0.319 \mathrm{MWh} / \mathrm{DD}$ and in 2007 at $2317 \mathrm{DD}$, the energy consumption was 669.37 MWh and the specific energy consumption energy - $0.289 \mathrm{MWh} / \mathrm{DD}$.

After the prescribed energy saving measures are implemented, the specific energy consumption in 2015 is $0.132 \mathrm{MWh} / \mathrm{DD}$, and in $2016-0.148 \mathrm{MWh} / \mathrm{DD}$.

When the model was calibrated in the Energy Efficiency Audit, a reference energy consumption for heating of $82.95 \mathrm{kWh} / \mathrm{m}^{2}$ was set for the year with the highest specific energy consumption.

After the energy-saving measures prescribed in the Energy Efficiency Survey, the reference energy consumption for heating is $38.62 \mathrm{kWh} / \mathrm{m}^{2}$. Comparing the reference energy costs for heating before and after the implementation of the energy saving measures show a real reduction of the energy consumption for heating (by avoiding the impact of climate through the heating dwellings) by $53.44 \%$.

Calculation of $\mathrm{CO}_{2}$ savings in accordance with Ordinance No. 7 of 2004 (2009, 2010, 2013, 2015) on energy efficiency, heat conservation and energy saving in buildings. The a coefficient is calculated, taking into account the losses for production, production and transmission of natural gas $\varepsilon_{i}=1.1$ [4]. A reference value of the ecological equivalence coefficient fi=202 $\mathrm{gCO}_{2} / \mathrm{kWh}$ is taken from the same ordinance (Table 3).

When comparing the energy costs for heating before and after the energy saving measures, there is a potential for reducing the costs actually incurred, with a thermal comfort of 513800 $\mathrm{kWh} / \mathrm{y}$ with an ecological equivalent of $114.16 \mathrm{t} \mathrm{CO}_{2}$ emitted.

Table 3. Emission savings of $\mathrm{CO}_{2}$

\begin{tabular}{|l|c|c|c|c|c|}
\hline \multicolumn{2}{|c|}{ Energy consumption for heating, $\mathrm{kWh} / \mathrm{y}$} & $\mathrm{e}_{\mathrm{i}}$ & $\begin{array}{c}\text { Primary } \\
\text { energy }\end{array}$ & $\mathrm{f}_{\mathrm{i}}$ & $\begin{array}{c}\text { Emissions } \\
\mathrm{CO}_{2}\end{array}$ \\
\cline { 3 - 6 } & - & $\mathrm{kWh} / \mathrm{y}$ & $\begin{array}{c}\mathrm{g} \\
\mathrm{CO}_{2} / \mathrm{kWh}\end{array}$ & $\mathrm{t}$ \\
\hline $\begin{array}{l}\text { Average annual cost before } \\
\text { ESM }\end{array}$ & 825460 & 1,1 & 908006 & 202 & 183,41 \\
\hline $\begin{array}{l}\text { Average annual cost before } \\
\text { ESM }\end{array}$ & 311660 & 1,1 & 342826 & 202 & 69,25 \\
\hline
\end{tabular}

\section{CONCLUSION}

The Energy Efficiency Audit of Vassil Karagyozov High school, Yambol, implemented by "Max Max Effect" ELTD, Sliven, provided for energy saving measures implemented during the implementation of the project.

A reference heating energy consumption of $38.62 \mathrm{kWh} / \mathrm{m}^{2}$ was determined after the renovation of the building. Comparing the reference energy costs for heating before and after 


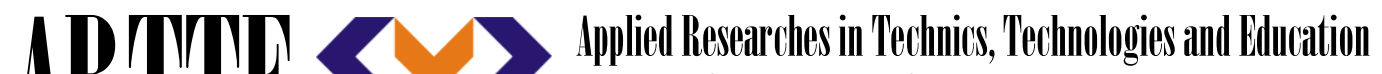 Journal of the Faculty of Technics and Technologies, Trakia University https://sites.google.com/a/trakia-uni.bg/artte/}

the implementation of the energy saving measures show a real decrease of the energy consumption for heating by $53.44 \%$.

The reduction of the necessary annual heating costs, provided thermal comfort, is 513800 $\mathrm{kWh} / \mathrm{y}$ with an ecological equivalent saving of $114.16 \mathrm{t} \mathrm{CO}_{2}$.

\section{REFERENCES}

[1] Energy Efficiency Act (promulgated in State Gazette, issue 98 of 14.11.2008, effective as of 05.07.2013, amended and supplemented, No. 59 of 05.07.2013) (in Bulgarian).

[2] Energy Efficiency Survey of Vassil Karagyozov High School, Yambol, En Max Effect EOOD, Sliven, June 2008 (in Bulgarian).

[3] Ordinance № РД-16-1058/ 10.12.2009 on the energy consumption and energy performance indicators for buildings has been determined (in Bulgarian).

[4] Ordinance No. 7 of 2004 on Energy Efficiency, Heat Conservation and Energy Savings in Buildings (Title amended, SG No. 85/2009, promulgated in SG 5 from 14.01.2005; and supplements, No. 85 of 27.10.2009, as amended, issue 88 of 06.11.2009, issue 92 of 20.11.2009, amended and supplemented, issue 2 from 08.01.2010, amended and supplemented, issue 80 of 13 September 2013, amended and supplemented, issue 93 of 25.10.2013, amended and supplemented, issue 27 of 14.04 .2015 in force from 15.07.2015) (in Bulgarian).

[5] Valchev G., N. Kaloyanov, V. Rasheva, M. Minchev, S. Tasheva. Energy Efficiency and Certification of Buildings - Science and Practice, National Conference with International Participation, Sliven, June 27-29, 2014. 